\title{
Prevalence and risk factors of microalbuminuria in Thai nondiabetic hypertensive patients
}

This article was published in the following Dove Press journal:

Vascular Health and Risk Management

10 March 2010

Number of times this article has been viewed

\section{Pongsathorn Gojaseni' \\ Angkana Phaopha' \\ Worawon Chailimpamontree' \\ Thaweepong Pajareya' \\ Anutra Chittinandana ${ }^{2}$ \\ 'Division of Nephrology, Department of Medicine, Bhumibol Adulyadej Hospital, Directorate of Medical Services, Royal Thai Air Force, Bangkok, Thailand; ${ }^{2}$ Department of Education, Directorate of Medical Services, Royal Thai Air Force, Bangkok, Thailand}

Correspondence: Pongsathorn Gojaseni Division of Nephrology, Department of Medicine Bhumibol Adulyadej Hospital, Directorate of Medical Services, Royal Thai Air Force, Bangkok, Thailand 10220 Tel +6625347284

Fax +6629946092

Email p.gojaseni@gmail.com
Purpose: To assess the prevalence and risk factors of microalbuminuria in nondiabetic hypertensive patients in Thailand.

Patients and methods: A cross-sectional study was performed during January to December 2007 at outpatients departments of Bhumibol Adulyadej hospital. Nondiabetic hypertensive patients without a history of pre-existing kidney diseases participated in this study. A questionnaire was used for collecting information on demographics, lifestyle, and family history of cardiovascular and kidney disease. Spot morning urine samples were collected for albuminuria estimation. Albuminuria thresholds were evaluated and defined using albumin-creatinine ratio (ACR).

Results: A total of 559 hypertensive patients ( 283 males, 276 females), aged $58.0 \pm 11.6$ years were enrolled in this study. Microalbuminuria (ACR 17 to $299 \mathrm{mg} / \mathrm{g}$ in males and 25 to $299 \mathrm{mg} / \mathrm{g}$ in females) was found in 93 cases $(16.6 \%)$ [15.0\%-18.2\%]. The independent determinants of elevated urinary albumin excretion in a multiple logistic regression model were; body mass index $\geq 30$ (odds ratio $(\mathrm{OR})=2.24,95 \%$ confidence intervals $(\mathrm{CI}): 1.33-3.76$ ) and dihydropyridine calcium channel blockers (DCCB) use (OR $=1.92,95 \% \mathrm{CI}: 1.22-3.02)$.

Conclusion: In Thai nondiabetic hypertensive patients, microalbuminuria was not uncommon. Obesity and use of dihydropyridine calcium channel blocker were found to be the important predictors. Prognostic value of the occurrence of microalbuminuria in this population remains to be determined in prospective cohort studies.

Keywords: microalbuminuria, hypertension, obesity, calcium channel blocker, metabolic syndrome

\section{Introduction}

Microalbuminuria has been shown to be associated with an increased risk of cardiovascular $^{1,2}$ and progressive kidney disease ${ }^{3-6}$ not only in diabetes but also in nondiabetic subjects. In addition, treatment aimed to reduce albuminuria levels have been shown to reduce the risk for cardiovascular events ${ }^{7}$ as well as kidney disease progression. ${ }^{8}$ In hypertensive subjects, microalbuminuria has now been considered as an essential component in the assessment of subclinical organ damage because its detection is easy and relatively inexpensive. ${ }^{9}$ In Thailand, however, reliable data about epidemiology of microalbuminuria in nondiabetic hypertensive patients and its association with cardiovascular and renal morbidity are limited. Previous study by Buranakitjaroen et al, included 505 Thai hypertensive subjects who attended the hypertension clinic at Siriraj Hospital, had reported the prevalence of microalbuminuria and its associated factors. ${ }^{10}$ However, the population in this study was the patients who were cared for by hypertensive specialists and might not represent the

submit your manuscript | www.dovepress.con 
whole hypertensive population of Thailand. Furthermore, the diagnostic test from this study was based on antibodybased dipstick rather than quantitative measuring of albuminuria. The aim of our study, therefore, was to assess the prevalence of microalbuminuria in hypertensive patients who attend general medical clinics. The screening method was antibody-based dipstick, but these were confirmed by urinary albumin creatinine ratio (ACR) in subjects who had tested positive with primary screening. The results from this study will provide us with a precise prevalence of microalbuminuria as well as associated factors and could demonstrate a value of screening for microalbuminuria in this population.

\section{Material and methods Study population}

A cross-sectional study was performed from January to December 2007 at 3 out-patient departments of directorate of medical services, Royal Thai Air Force including: (1) Department of preventive medicine, (2) Department of medicine, Bhumibol Adulyadej hospital, and (3) Primary care unit, Bhumibol Adulyadej hospital. Nondiabetic hypertensive patients, age $\geq 18$ years, without a history of pre-existing kidney diseases participated in this study. The major inclusion criteria were patients with hypertension (defined by sitting blood pressure (BP) $\geq 140 / 90 \mathrm{mmHg}$ in those not previously diagnosed with hypertension or those who were previously diagnosed with hypertension and reported current use of antihypertensive medications). Exclusion criteria were those with previously diagnosed diabetes mellitus or fasting blood glucose $\geq 126 \mathrm{mg} / \mathrm{dL}$, impaired kidney function (serum creatinine $>1.4 \mathrm{mg} / \mathrm{dL}$ in male, or $>1.2 \mathrm{mg} / \mathrm{dL}$ in female), or history associated with false positive albuminuria (fever, menstruation, urinary tract infection and post exercise). All participants gave written informed consent. This study was approved by Bhumibol Adulyadej hospital ethics committee.

\section{Data collection and evaluation}

The two page questionnaire was used for collecting information on demographics, lifestyle, current medical illness, and family history of cardiovascular and kidney disease. Duration of hypertension and data about antihypertensive medications were collected from medical records. All participants have their BP measured after a 5 minutes rest with a calibrated digital BP monitor. Systolic and diastolic BP measurements were calculated as the mean of the last two visits. Participants were also measured for weight, height, and waist circumference. Data about blood chemistry (fasting plasma glucose (FPG), creatinine ( $\mathrm{Cr}$ ), triglyceride (TG), total cholesterol (TC), high-density lipoprotein cholesterol (HDL-c), and uric acid (UA)) were collected from medical record within last 6 months.

Glomerular filtration rate (GFR) was estimated from the Modification of Diet in Renal Disease (MDRD) study equation as follows: ${ }^{11}$

Estimated GFR $\left(\mathrm{mL} / \mathrm{min} / 1.73 \mathrm{~m}^{2}\right)=186.3 *($ serum creatinine by Jaffe $)^{-1.154} *$ age $^{-0.203}$

(*0.742 for woman).

\section{Definitions}

Obesity and overweight were defined according to World Health Organization (WHO) guidelines. ${ }^{12}$ Subjects were classified as having impaired fasting glucose if fasting glucose $\geq 100 \mathrm{mg} / \mathrm{dL} .{ }^{13}$ Metabolic syndrome was defined according to the International Diabetes Federation (IDF) worldwide definition of metabolic syndrome (IDF 2005 guidelines $)^{14}$ that requires the presence of abdominal obesity according to ethnic-specific cutoff waist circumference (waist circumferences $>90 \mathrm{~cm}$. for men, or $>80 \mathrm{~cm}$. for women) plus any two or more of the following: (1) high TG ( $\mathrm{TG} \geq 150 \mathrm{mg} / \mathrm{dL}$ or treatment for this abnormality), (2) low HDL-c (HDL-c $<40 \mathrm{mg} / \mathrm{dL}$ in male subjects and $<50 \mathrm{mg} / \mathrm{dL}$ in female subjects or treatment for this abnormality), (3) high $\mathrm{BP}$ (systolic BP $\geq 130$ or diastolic $\mathrm{BP} \geq 85 \mathrm{mmHg}$ or treatment of hypertension), (4) high fasting glucose (FPG $\geq$ $100 \mathrm{mg} / \mathrm{dL}$ or previously diagnosed type 2 diabetes). High serum uric acid was defined as serum uric acid $>8.0 \mathrm{mg} / \mathrm{dL}$ for men, and $>7.0 \mathrm{mg} / \mathrm{dL}$ for women. High cholesterol was defined as taking cholesterol lowering medications, or serum cholesterol $>240 \mathrm{mg} / \mathrm{dL}$. Subjects were classified as smokers if they reported smoking or having smoked cigarettes during the previous 5 years. A family history of cardiovascular disease and kidney disease was considered present if at least one first degree relative had documented the diseases.

\section{Urinary albumin measurements}

All participants gave a spot morning urine sample for analysis. Screening for elevated urinary albumin excretion (UAE) was tested by antibody-based dipstick: Micral test strips (Roche Diagnostics, Basel, Switzerland) and reported as negative or positive (at least $20 \mathrm{mg} / \mathrm{L}$ ). Urine sample from participants who report positive from Micral test will be sent for quantitative measurement for albuminuria by using 
ACR. Albuminuria measured as urine albumin concentration (UAC) by the method of immunoturbidimetric technique with MODULAR ANALYTICS P 800 module analyzer (Roche Diagnostics, Mannheim, USA). Urine creatinine was measured using the modified Kinetic Jaffé (KJ) method using the same analyzer for albumin. Elevated UAE was defined if ACR was more than $17 \mathrm{mg} / \mathrm{g}$ creatinine in males and $25 \mathrm{mg} / \mathrm{g}$ creatinine in female as per standard guideline. ${ }^{15}$ Microalbuminuria was defined as ACR more than gender specific cutoff levels but less than $300 \mathrm{mg} / \mathrm{g}$ creatinine. Macroalbuminuria was defined as ACR more than $300 \mathrm{mg} / \mathrm{g}$ creatinine.

\section{Statistical analysis}

An overall prevalence and specific population prevalence of microalbuminuria were estimated along with their 95\% confidence interval (CI). Categorical variables were summarized using frequency and percentages \pm standard error (SE) while continuous variables were summarized using mean \pm standard deviations (SD) unless otherwise indicated. Descriptive statistics were used to compare the presence of elevated UAE with comparisons evaluated using t-tests for continuous variables and chi-square tests for categorical variables. The relationship between an elevation of UAE and covariates were assessed using a simple logistic regression model and reported as crude odds ratios (OR) with 95\% confident intervals (CI). Multiple logistic regression was then used to examine if the presence of elevated UAE was associated with obesity (BMI $\geq 30$ ), metabolic syndrome, abdominal obesity, high blood pressure ( $\mathrm{BP} \geq 130 / 85 \mathrm{mmHg}$ ), and the usage of calcium channel blockade medication. Results are presented as adjusted ORs with upper and lower 95\% CIs. $P$ values were two sided, and $P<0.05$ was considered to indicate statistical significance. All analyses were performed using SPSS statistical package version 15.0 (SPSS Inc, Chicago, IL, USA).

\section{Results}

\section{Demographic and clinical characteristics}

A total of 559 hypertensive patients, aged $58.0 \pm 11.6$ years were enrolled in this study. Demographic and baseline clinical characteristics of studied subjects were shown in Tables 1 and 2 respectively. Two hundred and eighty three were males and 276 were females. The mean duration of hypertension was $60.3 \pm 58.3$ months. Mean body mass index (BMI) was $26.1 \pm 6.9 \mathrm{~kg} / \mathrm{m}^{2}$ with ninety-seven patients $(17.4 \%)$ were found to be obesity $\left(\mathrm{BMI} \geq 30 \mathrm{~kg} / \mathrm{m}^{2}\right)$. Mean BMI of patients
Table I Demographic data of study subjects

\begin{tabular}{|c|c|c|}
\hline Characteristics & $\begin{array}{l}\text { Number } \\
n=559\end{array}$ & Percent \pm SE \\
\hline Age, year, mean $\pm S D$ & & $58.0 \pm 11.6$ \\
\hline \multicolumn{3}{|l|}{ Gender } \\
\hline Male & 283 & $50.6 \pm 2.1$ \\
\hline Female & 276 & $49.4 \pm 2.1$ \\
\hline Site I Preventive medicine & 169 & $30.2 \pm 1.9$ \\
\hline 2 Medicine & 276 & $49.4 \pm 2.1$ \\
\hline 3 Primary care unit & 114 & $20.4 \pm 1.7$ \\
\hline \multicolumn{3}{|l|}{ Region of origin $(n=552)$} \\
\hline Bangkok & 207 & $37 \pm 2.0$ \\
\hline Central & 218 & $39 \pm 2.0$ \\
\hline Northern & $4 \mid$ & $7.3 \pm 1.1$ \\
\hline North-eastern & 40 & $7.2 \pm 1.1$ \\
\hline Eastern & 31 & $5.5 \pm 1.0$ \\
\hline Southern & 15 & $2.7 \pm 0.6$ \\
\hline \multicolumn{3}{|l|}{ Educational level $(n=532)$} \\
\hline High school & 432 & $81.2 \pm 1.7$ \\
\hline University & 94 & $17.7 \pm 1.6$ \\
\hline Post-graduate & 6 & $\mathrm{I} . \mathrm{I} \pm 0.4$ \\
\hline \multicolumn{3}{|c|}{ Cardiovascular disease $(n=556)$} \\
\hline Yes & 31 & $5.6 \pm 1.0$ \\
\hline No & 525 & $94.4 \pm 1.0$ \\
\hline \multicolumn{3}{|c|}{ Cerebrovascular disease $(n=556)$} \\
\hline Yes & 18 & $3.2 \pm 0.7$ \\
\hline No & 538 & $96.8 \pm 0.7$ \\
\hline \multicolumn{3}{|c|}{ Family history of CVD $(n=5 \mid 4)$} \\
\hline Yes & 54 & $10.5 \pm 1.4$ \\
\hline No & 460 & $89.5 \pm 1.4$ \\
\hline \multicolumn{3}{|c|}{ Family history of CKD $(n=5 \mid 4)$} \\
\hline Yes & 34 & $6.6 \pm 1.1$ \\
\hline No & 480 & $93.4 \pm 1.1$ \\
\hline \multicolumn{3}{|l|}{ Smoking $(\mathrm{n}=537)$} \\
\hline Yes & 57 & $10.6 \pm 1.3$ \\
\hline No & 480 & $89.4 \pm 1.3$ \\
\hline
\end{tabular}

Abbreviations: CVD, cardiovascular disease; CKD, chronic kidney disease.

in the macroalbuminuria and microalbuminuria groups were significantly higher than those in the normoalbuminuria group ( $P=0.04$ and $P=0.03$, respectively). Mean estimated GFR in males and females were $77.7 \pm 16.8 \mathrm{~mL} / \mathrm{min} / 1.73 \mathrm{~m}^{2}$ and $80.8 \pm 19.2 \mathrm{~mL} / \mathrm{min} / 1.73 \mathrm{~m}^{2}$, respectively. Majority of subjects were not currently smokers (89.8.1\%). Underlying disease was also described. Prevalence of metabolic syndrome was about $41.3 \%$ whereas the prevalence of high cholesterol and impaired fasting glucose (IFG) were as high as $59.9 \%$ and $36.8 \%$. However, history of cardiovascular disease and cerebrovascular disease (CVA) were quite rare, ie, $5.6 \%$, and $3.2 \%$, respectively. Family history of cardiovascular disease and kidney disease were found in $10.5 \%$ and $6.6 \%$. 
Table 2 Clinical characteristics of study subjects

\begin{tabular}{|c|c|c|c|c|}
\hline Characteristics & $\begin{array}{l}\text { All } \\
(n=559)\end{array}$ & $\begin{array}{l}\text { Normo-albuminuria } \\
(\mathrm{n}=449)\end{array}$ & $\begin{array}{l}\text { Micro-albuminuria } \\
(n=93)\end{array}$ & $\begin{array}{l}\text { Macro-albuminuria } \\
(\mathrm{n}=17)\end{array}$ \\
\hline Age (years) & $58.0 \pm 11.6$ & $58.2 \pm 11.0$ & $57.3 \pm 13.7$ & $55.5 \pm 15.4$ \\
\hline Male gender (\%) & $50.6 \pm 2.1$ & $51.2 \pm 2.4$ & $50.5 \pm 5.2$ & $35.3 \pm 11.6$ \\
\hline Weight (kg) & $67.2 \pm 13.7$ & $66.6 \pm 13.4$ & $69.4 \pm 14.8$ & $69.2 \pm 16.1$ \\
\hline BMI $\left(\mathrm{kg} / \mathrm{m}^{2}\right)$ & $26.1 \pm 6.9$ & $25.9 \pm 7.2$ & $26.9 \pm 5.1$ & $28.0 \pm 5.9$ \\
\hline Obesity (\%) & $17.4 \pm 1.6$ & $14.3 \pm 1.7$ & $26.9 \pm 4.6^{*}$ & $47.1 \pm 12.1 * *$ \\
\hline Smoker (\%) & $10.2 \pm 1.2$ & $9.4 \pm 1.4$ & $16.1 \pm 3.8$ & 0 \\
\hline Systolic BP (mmHg) & $140.6 \pm 16.3$ & $139.0 \pm 15.2$ & $147.1 \pm 19.1 * *$ & $148.5 \pm 15.8^{*}$ \\
\hline Diastolic BP (mmHg) & $80.9 \pm 11.4$ & $80.4 \pm 1 \mathrm{I} .4$ & $82.9 \pm 11.0$ & $84.3 \pm 10.9$ \\
\hline Duration of HT (months) & $60.3 \pm 58.3$ & $57.3 \pm 55.7$ & $70.9 \pm 63.4$ & $80.1 \pm 83.6$ \\
\hline FPG $(\mathrm{mg} / \mathrm{dL})$ & $99.1 \pm 24.1$ & $97.4 \pm 14.7$ & $106.7 \pm 48.2^{*}$ & $103.5 \pm 12.0$ \\
\hline IFG (\%) & $36.8 \pm 2.1$ & $34.9 \pm 2.3$ & $48.2 \pm 5.2$ & $56.3 \pm 12.4$ \\
\hline eGFR $\left(\mathrm{ml} / \mathrm{min} / \mathrm{l} .73 \mathrm{~m}^{2}\right)$ & $79.3 \pm 17.8$ & $79.1 \pm 16.7$ & $79.4 \pm 21.2$ & $86.3 \pm 23.0$ \\
\hline Uric acid (mg/dL) & $6.3 \pm 3.0$ & $6.4 \pm 3.3$ & $6.2 \pm 1.6$ & $6.4 \pm 1.7$ \\
\hline Total cholesterol (mg/dL) & $198.7 \pm 39.5$ & $198.5 \pm 39.4$ & $198.1 \pm 40.7$ & $206.2 \pm 39.3$ \\
\hline High cholesterol (\%) & $59.9 \pm 2.1$ & $59.4 \pm 2.3$ & $58.1 \pm 5.1$ & $82.4 \pm 9.2$ \\
\hline Triglyceride (mg/dL) & $144.5 \pm 97.4$ & $14 \mid .2 \pm 102.4$ & $158.6 \pm 69.7$ & $153.8 \pm 88.2$ \\
\hline HDL-c (mg/dL) & $57.1 \pm 15.0$ & $57.6 \pm 15.3$ & $55.1 \pm 13.7$ & $56.3 \pm 14.4$ \\
\hline Uncontrolled BP (\%) & $52.8 \pm 2.1$ & $49.2 \pm 2.4$ & $66.7 \pm 4.9^{*}$ & $70.6 \pm 11.0$ \\
\hline $\begin{array}{l}\text { Number of antihypertensive } \\
\text { drug used }\end{array}$ & $1.64 \pm 0.98$ & $1.62 \pm 0.97$ & $1.7 \pm 0.98$ & $1.94 \pm 1.03$ \\
\hline METS-IDF (\%) & $41.3 \pm 2.1$ & $38.1 \pm 2.3$ & $54.8 \pm 5.2^{*}$ & $52.9 \pm 12.1$ \\
\hline
\end{tabular}

Abbreviations: BMI, body mass index; BP, blood pressure; HT, hypertension; FPG, fasting plasma glucose; IFG, impaired fasting glucose; eGFR, estimated glomerular filtration rate; HDL-c, high density lipoprotein cholesterol; METS-IDF, metabolic syndrome by IDF criteria.

$* * P<0.005, * P<0.05$ compared with normoalbuminuria group.

\section{Blood pressure control and} antihypertensive medication

Table 3 shows the extent of BP control achieved in study subjects. There were $306(47.2 \%)$ patients whose systolic BP and diastolic BP were both well controlled $(<140 /<90 \mathrm{mmHg})$, while normalization rates of either systolic BP $(<140 \mathrm{mmHg})$ or diastolic BP $(<90 \mathrm{mmHg})$ were $50.8 \%$ and $77.6 \%$, respectively. The presence of poorly controlled BP was seen more frequently in subjects with increased levels of albuminuria (Table 2). The mean number of antihypertensive agents was $1.64 \pm$ 0.98 and $54.9 \%$ of subjects were prescribed with combination therapy. Dihydropyridine calcium channel blockers (DCCB) were prescribed in $36.5 \%$ of patients, followed by a thiazide type diuretic (34.3\%) and ACE-I (33.3\%). Antihypertensive medications in study subjects according to albuminuria are shown in Table 4. Patients who were prescribed with DCCB have a significantly higher percentage of having microalbuminuria and macroalbuminuria compared with other classes of drugs.

\section{Prevalence of microalbuminuria}

Overall, the frequency of an elevated UAE by antibodybased dipstick of 559 screened population was 183 (32.7\%). However, 110 subjects who were test positive by antibody-based dipstick were confirmed by increased albumin-creatine ratio, giving a prevalence of $19.6 \%$ (95\% CI: $14.4 \%-18.8 \%)$. After excluding 17 persons with macroalbuminuria, microalbuminuria was found in 93 cases (16.6\%) [15.0\%-18.2\%]. The prevalence was similar in males and females, ie $16.6 \%$ (95\% CI: $14.4 \%-18.8 \%$ ) and $16.7 \%$ (95\% CI: $14.4 \%-18.9 \%)$, respectively. The genderspecific prevalences of albuminuria are shown in Table 5.

\section{Factors associated with elevated urinary albumin excretion}

Microalbuminuria and macroalbuminuria were combined and compared with the normoalbuminuria group for this analysis. Odds of having elevated UAE was estimated for those 13 factors (ie, age, sex, smoking status, BMI, waist circumference, duration of hypertension, BP control, 
Table 3 Antihypertensive medications used by study subjects categorized by blood pressure control

\begin{tabular}{|c|c|c|c|c|}
\hline $\begin{array}{l}\text { Antihypertensive } \\
\text { medication }\end{array}$ & $\begin{array}{l}<\mid 40 /<90 \mathrm{mmHg} \\
(\mathrm{n}=264)\end{array}$ & $\begin{array}{l}\geq \mid 40 / \geq 90 \mathrm{mmHg} \\
(\mathrm{n}=105)\end{array}$ & $\begin{array}{l}\geq \mid 40 /<90 \mathrm{mmHg} \\
(\mathrm{n}=\mathrm{I70})\end{array}$ & $\begin{array}{l}<\mid 40 / \geq 90 \\
\mathrm{mmHg} \\
(\mathrm{n}=\mathbf{2 0})\end{array}$ \\
\hline Total $(n=559)$ & $264(47.2 \%)$ & $105(18.8 \%)$ & 170 (30.4\%) & $20(3.6 \%)$ \\
\hline ACE-I $(n=186,33.3 \%)$ & $86(32.6 \%)$ & $32(30.5 \%)$ & $62(36.5 \%)$ & $6(30.0 \%)$ \\
\hline $\operatorname{ARB}(n=137,24.5 \%)$ & $50(18.9 \%)$ & $35(33.3 \%)^{*}$ & $48(28.2 \%)^{*}$ & $4(20.0 \%)$ \\
\hline Thiazide $(n=192,34.3 \%)$ & $92(34.8 \%)$ & $37(35.2 \%)$ & $56(32.9 \%)$ & $7(35.0 \%)$ \\
\hline DCCB $(n=204,36.5 \%)$ & $88(33.3 \%)$ & 44 (4I.9\%) & $66(38.8 \%)$ & $6(30.0 \%)$ \\
\hline$\beta$-Blocker $(n=178,31.8 \%)$ & 81 (30.7\%) & $27(25.7 \%)$ & $65(38.2 \%)$ & $5(25.0 \%)$ \\
\hline On $0-1$ class of drugs $(n=252,45.1 \%)$ & $128(48.5 \%)$ & 45 (42.9\%) & $68(40.0 \%)$ & II (55.0\%) \\
\hline On 2 classes of drugs $(n=204,36.3 \%)$ & $93(35.2 \%)$ & $42(40.0 \%)$ & $61(35.9 \%)$ & $8(40.0 \%)$ \\
\hline On $>=3$ classes of drugs $(n=103,18.6 \%)$ & $43(16.3 \%)$ & $18(17.1 \%)$ & $4 \mid(24.1 \%)^{*}$ & I (5.0\%) \\
\hline
\end{tabular}

Abbreviations: ACE-I, angiotensin converting enzyme-inhibitor; ARB, angiotensin receptor blocker; DCCB, dihydropyridine calcium channel blocker.

metabolic syndrome, FPG, cholesterol, triglyceride, HDL, and uric acid) that were suspected to be associated with elevated UAE (Table 6). In addition, data about current medication use (ie, renin angiotensin system (RAS) blockade, DCCB, number of antihypertensive medications, and statin) were also assessed. In univariate analysis, elevated UAE was associated with increased BMI, abdominal obesity, poor blood pressure control, metabolic syndrome, and the using of DCCB. These 5 factors were therefore considered simultaneously in the multivariated logistic model. After adjusting for confounding effects, the independent determinants of elevated UAE were; body mass index $\geq 30$ ( $\mathrm{OR}=2.24$, 95\% CI: $1.33-3.76)$ and DCCB use (OR $=1.92,95 \% \mathrm{CI}$ : 1.22-3.02). Subjects who had metabolic syndrome were about $20 \%$ higher risk ( $\mathrm{OR}=1.2,95 \% \mathrm{CI}: 1.0-1.4)$ of having elevated UAE than subjects who did not. However, this risk was only borderline significant.

\section{Discussion}

Microalbuminuria is common in Thai nondiabetic hypertensive patients with a prevalence of $16.6 \%$ and independently associated with obesity and certain classes of antihypertensive medication. A number of previous studies evaluated the prevalence of microalbuminuria in hypertensive patients has been published, which is varied from $16 \%$ in the USA, ${ }^{16}$ $11.5 \%$ to $30 \%$ in Europe, ${ }^{17-21}$ and 14.4 to $26.2 \%$ in Asian populations. ${ }^{22-24}$ This varying might be due to type of study-base (ie, community versus hospital-base), patient

Table 4 Antihypertensive medications used by study subjects according to albuminuria levels

\begin{tabular}{|c|c|c|c|c|}
\hline & $\begin{array}{l}\text { All } \\
(n=559)\end{array}$ & $\begin{array}{l}\text { Normo-albuminuria } \\
(n=449)\end{array}$ & $\begin{array}{l}\text { Micro-albuminuria } \\
(n=93)\end{array}$ & $\begin{array}{l}\text { Macro-albuminuria } \\
(n=17)\end{array}$ \\
\hline ACE-I & $186(33.3 \%)$ & $142(3 \mid .6 \%)$ & 35 (37.6\%) & $9(52.9 \%)$ \\
\hline ARB & I 37 (24.5\%) & II 6 (25.8\%) & 19 (20.4\%) & $2(11.8 \%)$ \\
\hline $\mathrm{DCCB}$ & $204(36.5 \%)$ & 147 (32.7\%) & $46(49.5 \%)^{*}$ & II (64.7\%)* \\
\hline NDCCB & $8(1.4 \%)$ & $7(1.6 \%)$ & I (I.I\%) & $0(0 \%)$ \\
\hline Thiazide diuretics & $192(34.3 \%)$ & 164 (36.5\%) & 25 (59.5\%) & $5(29.4 \%)$ \\
\hline Loop diuretics & $10(1.8 \%)$ & $7(1.6 \%)$ & $3(3.2 \%)$ & $0(0 \%)$ \\
\hline$\beta$-Blocker & $178(31.8 \%)$ & $|4|$ (3I.4\%) & $31(33.3 \%)$ & $6(35.3 \%)$ \\
\hline On 0-I class of drugs & $252(45.1 \%)$ & 204 (45.4\%) & $43(46.2 \%)$ & 5 (29.4\%) \\
\hline On 2 classes of drugs & $204(36.3 \%)$ & $168(37.4 \%)$ & $30(32.3 \%)$ & $6(35.3 \%)$ \\
\hline On $>=3$ classes of drugs & $103(18.6 \%)$ & 77 (I7.I\%) & $20(21.5 \%)$ & $6(35.3 \%)$ \\
\hline
\end{tabular}

Abbreviations: ACE-I, angiotensin converting enzyme-inhibitor; ARB, angiotensin receptor blocker; DCCB, dihydropyridine calcium channel blocker; NDCCB, nondihydropyridine calcium channel blocker.

$* P<0.05$ compared with other classes. 
Table 5 Prevalence of albuminuria according to gender

\begin{tabular}{|c|c|c|c|c|c|c|c|}
\hline \multirow[t]{2}{*}{ Gender } & \multirow[t]{2}{*}{$\mathbf{n}$} & \multicolumn{2}{|c|}{ Normoalbuminuria } & \multicolumn{2}{|c|}{ Microalbuminuria } & \multicolumn{2}{|c|}{ Macroalbuminuria } \\
\hline & & $\mathbf{n}$ & Prevalence (\%) & $\mathbf{n}$ & Prevalence (\%) & $\mathbf{n}$ & Prevalence (\%) \\
\hline Male & 283 & 230 & $81.3 \pm 2.3$ & 47 & $16.6 \pm 2.2$ & 6 & $2.1 \pm 0.8$ \\
\hline Female & 276 & 219 & $79.3 \pm 2.4$ & 46 & $16.7 \pm 2.2$ & 11 & $4.0 \pm 0.8$ \\
\hline Overall & 559 & 449 & $80.3 \pm 1.7$ & 93 & $16.6 \pm 1.6$ & 17 & $3.0 \pm 0.7$ \\
\hline
\end{tabular}

characteristics, urine sample collection, and the methods of tests used. In Thailand, a study at Siriraj hospital had reported a prevalence of microalbuminuria, assessed by antibodybased dipstick, of $18.6 \%$ comparable to our study. ${ }^{10}$ However, it should be kept in mind that prevalence of microalbuminuria by dipstick screening in our study was $32.7 \%$ using the same cut off value at $20 \mathrm{mg} / \mathrm{L}$. There had been a study showing that screening of microalbuminuria by Micral test strips had a low positive predictive value of $69 \% .^{25}$ Therefore, we could say that our population had much higher prevalence of microalbuminuria. These results could be explained by a difference in population characteristics as following: (1) patients enrolled in Siriraj study were from a hypertension clinic and cared for by a hypertensive specialists; (2) majority of patients taken on combination antihypertensive medication with a mean number of $2.6 \pm 0.8$; and (3) higher $\mathrm{BP}$ normalization rate $(\mathrm{BP}<140 / 9078.8 \%$ compared with $47.2 \%$ ). Better BP control could explain the lower prevalence of target organ damage.

Various studies have documented risk factors associated with microalbuminuria. Among those factors, obesity has been shown to be important in many studies. ${ }^{26-29}$ To the best of our knowledge, this is the first study to show that increased urinary albumin excretion is associated with obesity in the Thai population. The importance of obesity in the development of albuminuria has been studied in experimental models. It was shown that obesity, by several mechanisms, can lead to glomerular hyperfiltration and subsequently developed early histological changes together with the development of albuminuria. ${ }^{30}$ Recent

Table 6 Odds ratio and $95 \%$ confidence interval for presence of elevated urinary albumin excretion: univariate and multivariate analyses

\begin{tabular}{|c|c|c|c|c|c|c|}
\hline Variables & Univariate & $95 \% \mathrm{Cl}$ & $P$-value & Multivariate & $95 \% \mathrm{Cl}$ & $P$-value \\
\hline $\mathrm{BMI} \geq 30 \mathrm{~kg} / \mathrm{m}^{2}$ & 2.58 & $1.59-4.19$ & $<0.001$ & 2.24 & $1.33-3.76$ & 0.002 \\
\hline $\mathrm{DCCB}$ & 2.20 & $1.44-3.36$ & $<0.001$ & 1.92 & I.22-3.02 & 0.005 \\
\hline METS-IDF & 1.95 & $1.28-2.97$ & 0.002 & 1.65 & $1.02-2.67$ & 0.043 \\
\hline Abdominal obesity-Asia & 1.78 & $1.06-2.99$ & 0.028 & 1.63 & $0.95-2.80$ & 0.077 \\
\hline $\mathrm{BP} \geq 130 / 85 \mathrm{mmHg}$ & 1.84 & $1.05-3.22$ & 0.033 & 1.49 & $0.83-2.67$ & 0.182 \\
\hline Age $\geq 60$ years & 0.85 & $0.55-1.29$ & 0.444 & & & \\
\hline Female gender & 1.13 & $0.74-1.7 \mid$ & 0.567 & & & \\
\hline Smoking & 1.57 & $0.83-2.96$ & 0.163 & & & \\
\hline $\mathrm{HT} \geq 10$ years & 1.77 & I.10-2.85 & 0.019 & & & \\
\hline $\mathrm{FPG} \geq 100 \mathrm{mg} / \mathrm{dL}$ & 1.49 & $0.96-2.29$ & 0.073 & & & \\
\hline $\mathrm{TG}>150 \mathrm{mg} / \mathrm{dL}$ & 1.42 & $0.92-2.18$ & 0.110 & & & \\
\hline Low HDL-c & 1.38 & $0.82-2.33$ & 0.229 & & & \\
\hline High uric acid & 1.36 & $0.84-2.20$ & 0.217 & & & \\
\hline High Cholesterol & 1.02 & $0.56-1.85$ & 0.951 & & & \\
\hline ACE-I or ARB & 0.97 & $0.64-1.48$ & 0.895 & & & \\
\hline Anti $\mathrm{HT} \geq 3$ classes & $\mathrm{I} .48$ & $0.90-2.46$ & 0.125 & & & \\
\hline Statins & 1.18 & $0.78-1.80$ & 0.437 & & & \\
\hline
\end{tabular}

Abbreviations: BMI, body mass index; DCCB, dihydropyridine calcium channel blocker; METS-IDF, metabolic syndrome by IDF criteria; BP, blood pressure; HT, hypertension; FPG, fasting plasma glucose; TG, triglyceride; HDL-c, high density lipoprotein cholesterol; ACE-I, angiotensin converting enzyme-inhibitor; ARB, angiotensin receptor blocker. 
studies by Goumenos et al demonstrated histological lesions such as glomerulomegaly as well as focal segmental glomeruloscerosis in patients with morbid obesity even before the appearance of microalbuminuria. ${ }^{31}$ Furthermore, microalbuminuria in nondiabetic subjects might be part of insulin resistance syndrome. ${ }^{32,33}$ Many risk factors associated with microalbuminuria (eg, hypertension, hyperglycemia, obesity, hyperlipidemia) are well-known components of insulin resistance syndrome (metabolic syndrome). Therefore, one could argue that insulin resistance is the key pathophysiologic mechanism to link between all of the above-mentioned risk factors and microalbuminuria. ${ }^{34}$ Nevertheless, results from our study showed only a borderline association between albuminuria and metabolic syndrome. This finding is similar to a study by Kitiyakara et al showing that metabolic syndrome was not associated with developing chronic kidney disease in the Thai population when using IDF definition with Asianspecific cutoff waist circumference. ${ }^{35}$

Another finding from this study is the association between certain classes of antihypertensive medication and urinary albumin excretion. In our study, patients currently taking DCCB had a higher prevalence of microalbuminria compared with other classes. This relation was independent from blood pressure level. In several studies, DCCB were not shown to reduce proteinuria levels and to slow the progression of CKD despite achieving BP goals comparable to that achieved with angiotensin converting enzymeinhibitor (ACE-I) or angiotensin receptor blocker (ARB). ${ }^{36}$ Results from animal studies suggested that DCCB markedly attenuate the autoregulatory ability of glomeruli. ${ }^{37,38}$ This would result in an increase in glomerular capillary pressure and albuminuria unless BP was reduced to level below $120 \mathrm{mmHg} .{ }^{39}$ The result from our study may support this theory since the majority of study subjects did not have good BP control. Nevertheless, this association in our study only showed cross-sectional but not a cause-effect relationship.

It has been accepted that screening for microalbuminuria is cost-effectiveness in the prevention of progressive kidney disease in diabetic patients. ${ }^{40,41}$ However, there is still a debate concerning whether or not that benefit would be the same in other high risk groups such as hypertensive patients. According to the 2007 European Society of Hypertension (ESH)/European Society of Cardiology (ESC) guidelines, microalbuminuria has been considered as a recommended test for risk stratification. ${ }^{9}$ However, this recommendation has not been implemented for hypertensive care in Thailand. Consequently, physicians and health care providers are still reluctant to screen for microalbuminuria and to follow this screening with appropriate treatment in these populations. Atthobari et al have studied the issue of the cost-effectiveness of screening for albuminuria and the subsequent treatment of individuals with microalbuminuria with an ACE inhibitor. Although this approach was not cost-effective in terms of preventing end stage renal disease, it was cost-effective in preventing short term outcomes like cardiovascular events. ${ }^{42}$ Our study reported the prevalence of microalbuminuria in nondiabetic hypertensive patients to be high enough to make screening worthwhile. Moreover, the screening method is easy and with an acceptable cost. Taking these evidences together with the Wilson-Jungner criteria for screening programs, ${ }^{43}$ we conclude that screening for albuminuria may prove to be useful in early risk assessment and prevention of cardiovascular disease in hypertensive patients in Thailand.

Our study has some limitations. Urinary albumin was measured on only a single occasion. Thus, we cannot exclude the possibility of false positive/negative test. Our study, however, corrected for some potential variability in urine concentrations by measuring for urinary creatinine excretion and used ACR in the analysis. Secondly, a crosssectional design limits the ability to show any cause-effect relationship between risk factors and albuminuria as well as cardiovascular and renal outcomes. Further longitudinal studies of the natural course of microalbuminuria in nondiabetic hypertensive subjects will answer these questions.

\section{Conclusion}

In summary, microalbuminuria is not uncommon in Thai nondiabetic hypertensive subjects. Obesity and the use of dihydropyridine calcium channel blockers were found to be the important predictors. Prognostic value of the occurrence of microalbuminuria in this population remains to be determined in prospective cohort studies.

\section{Acknowledgments}

We thank Miss Punnee Amornithikul and Miss Kwanruan Narkkaew for their support in data collection, and acknowledge group captain Traisit Tassanavitate, Chief of the Department of Preventive Medicine, Royal Thai Air Force, for his support during studies in the Department of Preventive Medicine. 


\section{Disclosures}

No conflicts of interest were declared in relation to this paper.

\section{References}

1. Borch-Johnsen K, Feldt-Rasmussen B, Strandgaard S, Schroll M, Jensen JS. Urinary albumin excretion. An independent predictor of ischemic heart disease. Arterioscler Thromb Vasc Biol. 1999;19(8):1992-1997.

2. Hillege HL, Fidler V, Diercks GF, et al. Urinary albumin excretion predicts cardiovascular and noncardiovascular mortality in general population. Circulation. 2002;106(14):1777-1782.

3. Iseki $\mathrm{K}$, Ikemiya $\mathrm{Y}$, Iseki $\mathrm{C}$, Takishita $\mathrm{S}$. Proteinuria and the risk of developing end-stage renal disease. Kidney Int. 2003;63(4): $1468-1474$.

4. Mogensen CE. Microalbuminuria predicts clinical proteinuria and early mortality in maturity-onset diabetes. $N$ Engl $J$ Med. 1984;310(6):356-360.

5. Mogensen CE, Christensen CK. Predicting diabetic nephropathy in insulin-dependent patients. N Engl J Med. 1984;311(2):89-93.

6. Verhave JC, Gansevoort RT, Hillege HL, Bakker SJ, De Zeeuw D, de Jong PE. An elevated urinary albumin excretion predicts de novo development of renal function impairment in the general population. Kidney Int Suppl. 2004:S18-S21.

7. Asselbergs FW, Diercks GF, Hillege HL, et al. Effects of fosinopril and pravastatin on cardiovascular events in subjects with microalbuminuria. Circulation. 2004;110(18):2809-2816.

8. Parving HH, Lehnert H, Brochner-Mortensen J, Gomis R, Andersen S, Arner P. The effect of irbesartan on the development of diabetic nephropathy in patients with type 2 diabetes. $N$ Engl J Med. 2001;345(12):870-878.

9. Mancia G, De Backer G, Dominiczak A, et al. 2007 Guidelines for the management of arterial hypertension: The task force for the management of arterial hypertension of the European Society of Hypertension (ESH) and of the European Society of Cardiology (ESC). J Hypertens. 2007;25(6):1105-1187.

10. Buranakitjaroen P, Phoojaroenchanachai M, Saravich S. Microalbuminuria in Thai essential hypertensive patients. J Int Med Res. 2007;35(6):836-847.

11. Levey AS, Bosch JP, Lewis JB, Greene T, Rogers N, Roth D. A more accurate method to estimate glomerular filtration rate from serum creatinine: a new prediction equation. Modification of diet in renal disease study group. Ann Intern Med. 1999;130(6):461-470.

12. World Health Organization. Obesity: preventing and managing the global epidemic. Report of a WHO convention, Geneva, 1999. WHO technical report series 894. Geneva 2000.

13. American Diabetes Association: Position statement on diagnosis and classification of diabetes mellitus. Diabetes Care. 2007;30(Suppl 1): S42-S47.

14. Alberti KG, Zimmet P, Shaw J. Metabolic syndrome-a new world-wide definition. A consensus statement from the International Diabetes Federation. Diabet Med. 2006;23(5):469-480.

15. Levey AS, Coresh J, Balk E, et al. National Kidney Foundation practice guidelines for chronic kidney disease: evaluation, classification, and stratification. Ann Intern Med. 2003;139(2):137-147.

16. Jones CA, Francis ME, Eberhardt MS, et al. Microalbuminuria in the US population: third National Health and Nutrition Examination Survey. Am J Kidney Dis. 2002;39(3):445-459.

17. Yuyun MF, Khaw KT, Luben R, et al. Microalbuminuria independently predicts all-cause and cardiovascular mortality in a British population: The European Prospective Investigation into Cancer in Norfolk (EPICNorfolk) population study. Int J Epidemiol. 2004;33(1):189-198.
18. Hallan H, Romundstad S, Kvenild K, Holmen J. Microalbuminuria in diabetic and hypertensive patients and the general populationconsequences of various diagnostic criteria-the Nord-Trondelag Health Study (HUNT). Scand J Urol Nephrol. 2003;37(2):151-158.

19. Hillege HL, Janssen WM, Bak AA, et al. Microalbuminuria is common, also in a nondiabetic, nonhypertensive population, and an independent indicator of cardiovascular risk factors and cardiovascular morbidity. J Intern Med. 2001;249(6):519-526.

20. Luft FC, Agrawal B. Microalbuminuria as a predictive factor for cardiovascular events. J Cardiovasc Pharmacol. 1999;33 Suppl 1: S11-S15; discussion S41-S43.

21. Pontremoli R, Sofia A, Ravera M, et al. Prevalence and clinical correlates of microalbuminuria in essential hypertension: the MAGIC Study. Microalbuminuria: A Genoa investigation on complications. Hypertension. 1997;30(5):1135-1143.

22. Col M, Ocaktan E, Ozdemir O, Yalcin A, Tuncbilek A. Microalbuminuria: prevalence in hypertensives and diabetics. Acta Med Austriaca. 2004;31(1):23-29.

23. Fischbacher CM, Bhopal R, Rutter MK, et al. Microalbuminuria is more frequent in South Asian than in European origin populations: a comparative study in Newcastle, UK. Diabet Med. 2003;20(1):31-36.

24. Tomura S, Kawada K, Saito K, et al. Prevalence of microalbuminuria and relationship to the risk of cardiovascular disease in the Japanese population. Am J Nephrol. 1999;19(1):13-20.

25. Parikh CR, Fischer MJ, Estacio R, Schrier RW. Rapid microalbuminuria screening in type 2 diabetes mellitus: simplified approach with Micral test strips and specific gravity. Nephrol Dial Transplant. 2004;19(7): 1881-1885.

26. Pinto-Sietsma SJ, Navis G, Janssen WM, de Zeeuw D, Gans RO, de Jong PE. A central body fat distribution is related to renal function impairment, even in lean subjects. Am J Kidney Dis. 2003;41(4):733-741.

27. Ribstein J, du Cailar G, Mimran A. Combined renal effects of overweight and hypertension. Hypertension. 1995;26(4):610-615.

28. Valensi P, Assayag M, Busby M, Paries J, Lormeau B, Attali JR. Microalbuminuria in obese patients with or without hypertension. Int J Obes Relat Metab Disord. 1996;20(6):574-579.

29. Kawar B, Bello AK, El Nahas AM. High prevalence of microalbuminuria in the overweight and obese population: data from a UK population screening programme. Nephron Clin Pract. 2009;112(3): c205-c212.

30. Kasiske BL, Cleary MP, O'Donnell MP, Keane WF. Effects of genetic obesity on renal structure and function in the Zucker rat. J Lab Clin Med. 1985;106(5):598-604.

31. Goumenos DS, Kawar B, El Nahas M, et al. Early histological changes in the kidney of people with morbid obesity. Nephrol Dial Transplant. 2009;24(12):3732-3738.

32. Haffner SM, Gonzales C, Valdez RA, et al. Is microalbuminuria part of the prediabetic state? The Mexico City Diabetes Study. Diabetologia. 1993;36(10):1002-1006.

33. Mykkanen L, Zaccaro DJ, Wagenknecht LE, Robbins DC, Gabriel M, Haffner SM. Microalbuminuria is associated with insulin resistance in nondiabetic subjects: the insulin resistance atherosclerosis study. Diabetes. 1998;47(5):793-800.

34. Kubo M, Kiyohara Y, Kato I, et al. Effect of hyperinsulinemia on renal function in a general Japanese population: the Hisayama study. Kidney Int. 1999;55(6):2450-2456.

35. Kitiyakara C, Yamwong S, Cheepudomwit S, et al. The metabolic syndrome and chronic kidney disease in a Southeast Asian cohort. Kidney Int. 2007;71(7):693-700.

36. Bakris GL, Weir MR, Secic M, Campbell B, Weis-McNulty A. Differential effects of calcium antagonist subclasses on markers of nephropathy progression. Kidney Int. 2004;65(6):1991-2002.

37. Bakris GL, Griffin KA, Picken MM, Bidani AK. Combined effects of an angiotensin converting enzyme inhibitor and a calcium antagonist on renal injury. $J$ Hypertens. 1997;15(10):1181-1185. 
38. Tarif N, Bakris GL. Preservation of renal function: the spectrum of effects by calcium-channel blockers. Nephrol Dial Transplant. 1997;12(11):2244-2250.

39. Griffin KA, Picken MM, Bakris GL, Bidani AK. Class differences in the effects of calcium channel blockers in the rat remnant kidney model. Kidney Int. 1999;55(5):1849-1860.

40. Palmer AJ, Annemans L, Roze S, et al. Cost-effectiveness of early irbesartan treatment versus control (standard antihypertensive medications excluding ACE inhibitors, other angiotensin-2 receptor antagonists, and dihydropyridine calcium channel blockers) or late irbesartan treatment in patients with type 2 diabetes, hypertension, and renal disease. Diabetes Care. 2004;27(8):1897-1903.
41. Rippin JD, Barnett AH, Bain SC. Cost-effective strategies in the prevention of diabetic nephropathy. Pharmacoeconomics. 2004; 22(1):9-28.

42. Atthobari J, Asselbergs FW, Boersma C, et al. Cost-effectiveness of screening for albuminuria with subsequent fosinopril treatment to prevent cardiovascular events: a pharmacoeconomic analysis linked to the prevention of renal and vascular endstage disease (PREVEND) study and the prevention of renal and vascular endstage disease intervention trial (PREVEND IT). Clin Ther. 2006;28(3):432-444.

43. Wilson JM, Jungner YG. Principles and practice of mass screening for disease. Bol Oficina Sanit Panam.1968;65(4):281-393.

\section{Publish your work in this journal}

Vascular Health and Risk Management is an international, peerreviewed journal of therapeutics and risk management, focusing on concise rapid reporting of clinical studies on the processes involved in the maintenance of vascular health; the monitoring, prevention and treatment of vascular disease and its sequelae; and the involvement of metabolic disorders, particularly diabetes. This journal is indexed on PubMed Central and MedLine. The manuscript management system is completely online and includes a very quick and fair peer-review system, which is all easy to use. Visit http://www.dovepress.com/ testimonials.php to read real quotes from published authors.

Submit your manuscript here: http://www.dovepress.com/vascular-health-and-risk-management-journal 